\title{
RANCANG BANGUN GAME EDUKASI SEBAGAI MEDIA PEMBELAJARAN MATA KULIAH PRAKTIK TEKNIK DIGITAL
}

\author{
Ariadie Chandra Nugraha ${ }^{1}$, Moh.Khairudin ${ }^{2}$, Deny Budi Hertanto ${ }^{3}$ \\ 1,2,3 Jurusan Pendidikan Teknik Elektro Universitas Negeri Yogyakarta \\ Email: ariadie@uny.ac.id
}

\begin{abstract}
This paper aims to explain the process to: (1) develop the education game as a learning medium for basics of digital system practice and (2) assess the feasibility of the education game as a learning medium for digital techniques practice. The development model used in this research is the ADDIE that consist of (a) Analysis, (b) Design, (c) Development, (d) Implementation, and (e) Evaluation. The results of this process were: (1) The development of the "Master of Digital" game model ADDIE produced educational game that consists of main, levels, high scores, and settings page. (2) Based on an assessment by material experts obtained an average score value of 72 from the mean maximum score value of 84 with the category of "very feasible". Based on an assessment by media experts obtained an average score value of 84 from the mean maximum score value of 104 with the category of "feasible". Based on students assessment obtained an average score value of 54,61 from the mean maximum score value of 80 with the category of "feasible".
\end{abstract}

Keywords: education game, learning medium, basics of digital system

\begin{abstract}
ABSTRAK
Tulisan ini bertujuan untuk menjelaskan proses: (1) mengembangkan game edukasi pada mata kuliah praktik teknik digital, dan (2) meguji kelayakan dari game edukasi pada mata kuliah praktik teknik digital.. Model pengembangan yang digunakan di dalam penelitian ini adalah ADDIE yang terdiri dari (a) Analisis, (b) Desain, (c) Development, (d) Implementasi, dan (e) Evaluasi. Hasil proses ini adalah : (1) Pengembangan game "Master of Digital" dengan model ADDIE menghasilkan game edukasi yang terdiri dari halaman utama, level game, skor tertinggi, dan pengaturan. (2) Berdasarkan penilaian oleh ahli materi didapatkan rerata skor 73 dari rerata skor maksimal 84 dengan kategori "sangat layak". Berdasarkan penilaian oleh ahli media didapatkan rerata skor 84 dari rerata skor maksimal 104 dengan kategori "layak". Berdasarkan penilaian oleh mahasiswa didapatkan rerata skor 54,61 dari rerata skor maksimal 80 dengan kategori "layak".
\end{abstract}

Kata kunci: game edukasi, media pembelajaran, teknik digital

\section{PENDAHULUAN}

Pada proses pembelajaran ada tiga faktor penting yang mempengaruhi kualitas dari suatu proses pembelajaran. Selain sumber belajar dan penerima, ada juga media pembelajaran sebagai perantara yang merupakan faktor penting dalam penyamapaian informasi yang baik dari sumber ke penerima. Menurut Nana Sudjana dan Ahmad Rivai (2013) penggunaan media pembelajaran dalam suatu proses pembelajaran akan memberikan dampak pada kualitas dari proses pembelajaran tersebut. Suatu media pembelajaran diharapkan dapat menunjang atau membantu dosen dalam penggunaan metode belajar di dalam kelas. Media pembelajaran yang baik adalah media pembelajaran yang sesuai dengan lingkungan belajar yang ada.

Dewasa ini media pembelajaran sudah mengalami banyak variasi seiring dengan perkembangan teknologi. Penggunaan komputer dalam berbagai media pembelajaran merupakan salah satu wujud dari perkembangan teknologi daam dunia pendidikan. Ariesto Hadi Soetopo (2012) menyatakan bahwa media pembelajaran berbasis komputer merupakan suatu media pembelajaran yang menggunakan komputer sebagai alat bantu utama dalam proses penyampaian meteri pada proses pembelajaran. Alat bantu yang bisa digunakan 
tersebut bisa berupa tutorial, simulasi, dan game atau permainan. Dengan alat bantu menggunakan komputer tersebut diharapkan proses pembelajaran bisa berjalan lebih variatif dan tidak membosankan sehingga dapat meningkatkan hasi belajar mahasiswa.

Salah satu teknologi berbasis komputer yang sedang dikembangkan saat ini adalah permainan atau games. Rusman, dkk (2013:1920) menyatakan bahwa permainan sebagai media pembelajaran dapat membuat suasana pembelajaran menjadi lebih menyenangkan dan dapat menegurangi kejenuhan terhadap informasi atau materi yang disampaikan oleh dosen kepada mahasiswa. Game yang dibuat sebagai media pembelajaran diharapkan akan memberikan dampak terhadap mahasiswa untuk belajar aktif dalam selama proses pembelajaran.

Jurusan Pendidikan Teknik Elektro Universitas Negeri Yogyakarta merupakan salah satu jurusan terbaik di Fakultas Teknik Universitas Negeri Yogyakarta. Oleh karenanya, proses penyelenggaraan kegiatan pendidikan harus sejalan dengan kemajuan teknologi. Tujuannya adalah agar lulusan dapat memilih untuk bekerja di dunia industri maupun melanjutkan pedidikan ke jenjang yang lebih tinggi. Tujuan tersebut dapat diwujudkan dengan usaha yang keras dan strategi-strategi matang dalam proses pendidikan yang akan dilaksanakan.

Berdasarkan pengamatan peneliti tertanggal 10 Agustus hingga 12 September 2015 di Jurusan Pendidikan Teknik Elektro Universitas Negeri Yogyakarta, ada beberapa hal yang penulis temukan. Hal tersebut terdapat pada Mata Kuliah Teknik Digital. Penulis menemukan beberapa hal yang melatarbelakangi penelitian ini. Dosen masih menjelaskan materi dengan model ceramah yang artinya hal ini masih mengacu pada model pembelajaran konvensional. Dosen menjelaskan materi kepada Mahasiswa dengan bantuan slide power point dengan beberapa kalimat di dalamnya. Akibatnya banyak di antara Mahasiswa yang sibuk dengan melakukan hal lain yang tidak sewajarnya. Mahasiswa ada yang asik bermain dengan teman sebangku, ada yang tidur, bahkan ada yang dengan sembunyisembunyi bermain dengan telepon genggam yang sudah jelas dilarang oleh pihak jurusan. Akhirnya apa yang dijelaskan oleh dosen tidak dapat diterima dengan baik oleh mahasiswa. Hal ini dibuktikan ketika dosen menawarkan kepada mahasiswa untuk bertanya, sangat jarang dari mahasiswa yang mengajukan pertanyaan. Bahkan dalam suatu sesi tidak ada satu pun mahasiswa yang mengajukan pertanyaan. Selain itu dalam ulangan harian banyak mahasiswa yang tidak dapat mengerjakan sendiri soal yang sudah diberikan. Ada beberapa diantara mereka yang mencoba mencontek pekerjaan teman sebangkunya atau sebelahnya.

Berdasarkan permasalahan tersebut di atas, penulis mencoba memberikan penyelesaian atau solusi dari permasalahan yang ada dengan membuat suasana belajar yang baru bagi mahasiswa. Peneliti mencoba membuat media pembelajaran yang dapat diterima dengan baik oleh semua mahasiswa. Media pembelajaran tersebut adalah melalui game edukasi. Melalui game edukasi ini, mahasiswa dapat memeperoleh suasana belajar yang baru dengan kualitas materi yang disesuaikan dengan model pembelajaran modern, yaitu student centre learning. Game edukasi ini nantinya akan disusun dengan genre adventure sehingga diharapkan akan membuat Mahasiswa untuk menjadi tertantang dalam menyelesaikan semua level di dalamnya. Peneliti membuat game ini dengan judul "Master of Digital". Melalui media pembelajaran ini diharapkan dapat meningkatkan tingkat pemahaman mahasiswa pada materi teknik digital dengan suasana belajar baru yang menyenangkan

\section{METODE}

Prosedur pengembangan di dalam penelitian ini terdiri dari lima tahap. Semua tahapan yang dilakukan disesuaikan dengan model pengembangan ADDIE, yaitu analisis, 
desain, pengembangan, implementasi, dan evaluasi. Semua tahapan tersebut dapat dijelaskan pada penjabaran berikut.

\section{Analisis}

Kegiatan analisis dilakukan dengan mengamati masalah, potensi, dan keadaan pembelajaran di Jurusan Pendidikan Teknik Elektro Universitas Negeri Yogyakarta. Hal-hal yang terdapat pada proses pembelajaran dijadikan sebagai bahan observasi, seperti model pembelajaran, strategi pembelajaran, dan media pembelajaran. Selain itu administrasi dosen seperti silabus, RPP, dan materi pembelajaran juga termasuk dalam bahan observasi .

\section{Desain}

Tahap pengembangan produk dimulai dengan perencanaan atau pembuatan konsep awal produk. Hal ini bertujuan agar produk yang dibuat dapat berfungsi dengan baik sesuai dengan kebutuhan masyarakat. Tahapan ini mencakup pembuatan story board, gameplay, dan perencanaan materi. Game ini bercerita tentang seorang mahasiswa dari Jurusan Teknik Mekatronika yang telah memiliki kemampuan dasar dalam Mata Kuliah Teknik Digital. Keahlian yang diperoleh belum memiliki kualifikasi yang baik tentang Teknik Digital.

\section{Development}

Tahap pengembangan dilakukan setelah tahap desain selesai. Tahap tersebut adalah proses pengembangan konsep menjadi game yang sesungguhnya. Tahap pengembangan meliputi pembuatan layout, penyusunan program, pengembangan butir soal, dan pengembangan animasi. Semua tahapan tersebut harus dilaksanakan sesuai prosedur agar produk yang dibuat benar-benar dapat memenuhi standar kelayakan. Game edukasi harus divalidasi terlebih dahulu sebelum diimplementasikan di dalam kelas. Berdasarkan data hasil validasi ahli materi dan ahli media, kemudian dilakukan pengembangan lebih lanjut sesuai dengan masukan ahli. Game yang sudah dikembangkan ini selanjutnya siap untuk diimplementasikan di dalam kelas.

\section{Implementation}

Implementasi dari penelitian ini yaitu penerapan penggunaan media pembelajaran berbasis game edukasi yang dilaksanakan di Jurusan Pendidikan Teknik Elektro Universitas Negeri Yogyakarta. Setiap mahasiswa dengan komputer masing-masing yang telah disediakan oleh pihak Jurusan mencoba mengoperasikan game edukasi ini.

\section{Evaluasi}

Ada empat proses yang harus dilalui pada tahap ini. Proses-proses tersebut diantaranya mendapatkan umpan balik pengguna akhir, mengumpulkan data, dan menganalisis data. Data yang sudah didapatkan dianalisis menggunakan analisis data kualitatif dan analisis data kuantitatif menggunakan bantuan perangkat lunak SPSS V23.

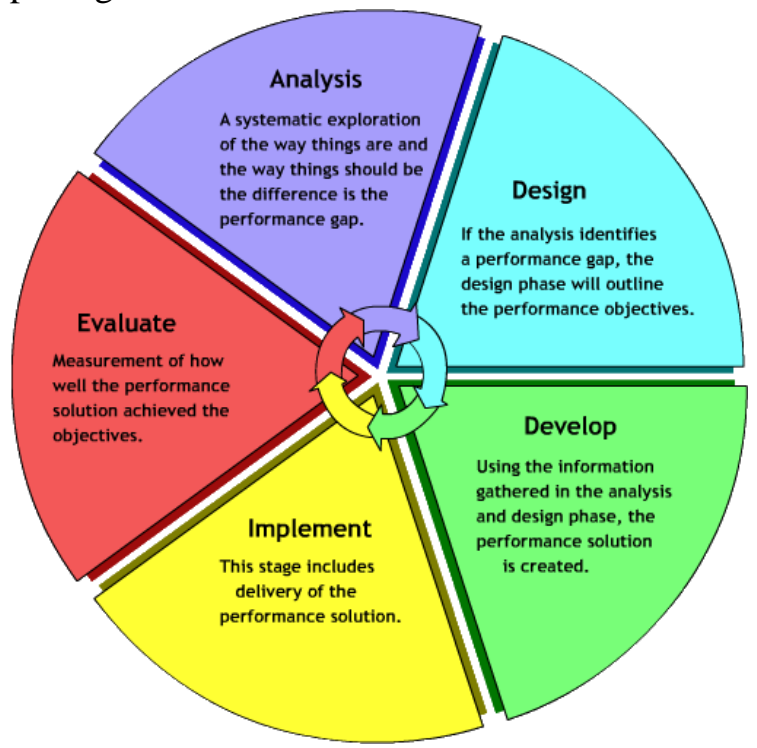

Gambar 1.Model ADDIE

(http://www.csuchico.edu/idts/addie.php)

Penelitian ini dilaksanakan di Jurusan Pendidikan Teknik Elektro Fakultas Teknik Universitas Negeri Yogyakarta pada tanggal 1 Januari - 30 Agustus 2016. Uji validasi materi dan uji validasi media dilaksanakan di Jurusan Pendidikan Teknik Elektro Fakultas Teknik Universitas Negeri Yogyakarta. Pengujian akhir oleh Mahasiswa dilaksanakan di Jurusan Pendidikan Teknik Elektro Universitas Negeri Yogyakarta. Subyek penelitian ini, yaitu game edukasi sebagai media pembelajaran mata kuliah praktik teknik digital. Metode 
pengumpulan data dilakukan dengan cara memberikan angket atau kuisioner kepada ahli materi, ahli media, dan Mahasiswa Jurusan Pendidikan Teknik Elektro Universitas Negeri Yogyakarta.

Instrumen yang digunakan berdasarkan The Learning Object Review Instrument (LORI) oleh Leacock dan Nesbit (2007). Instrumen tersebut berisi Aspek Kualitas Isi, Tujuan Pembelajaran, Umpan Balik dan Motivasi, Desain Presentasi, Penggunaan Interaksi, Aksesbilitas, Penggunaan Kembali.

Uji validitas dan reliabilitas dilakukan di dalam penelitian ini. Analisis data dilakukan dengan metode deskriptif kualitatif dan diskriptif kuantitatif. Data tersebut diperoleh dari hasil penilaian instrumen berupa angket yang berasal dari ahli materi, ahli media, dan Mahasiswa.

\section{HASIL DAN PEMBAHASAN}

\section{Pengembangan game edukasi}

\section{Pengembangan Game edukasi} berdasarkan model pengembangan ADDIE mencakup pengembangan materi dan media. Hasil produk berupa game edukasi yang dapat dilihat pada gambar berikut :

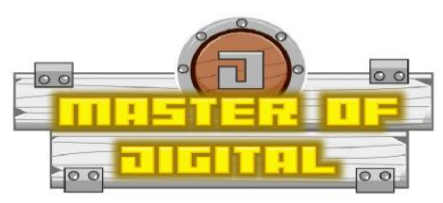

Gambar 2. Tampilan Awal

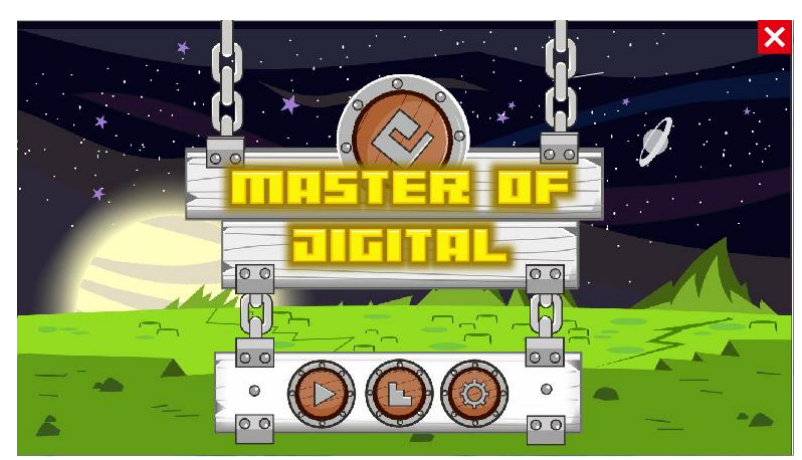

Gambar 3. Menu Utama
Menu utama dirancang sebagai jembatan penghubung dari semua scene permainan yang sudah dibuat. Komponen yang ada di dalam menu utama yaitu menu bermain, menu skor tertinggi, dan menu pengaturan. Sarana keluar dari permainan juga disediakan pada tombol keluar.

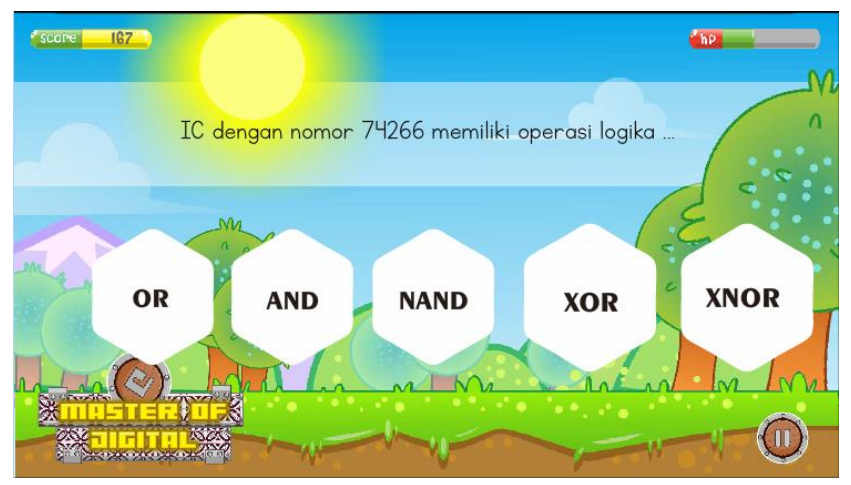

Gambar 4. Level 1

Level 1 berisi syarat yang harus diselesaikan pengguna sebelum resmi terdaftar sebagai agen "Master of Digital". Syarat tersebut yaitu tahap pretest. Tahap pretest harus diselesaikan dalam waktu tertentu yang disesuaikan dengan pergerakan animasi matahari pada tampilan game.

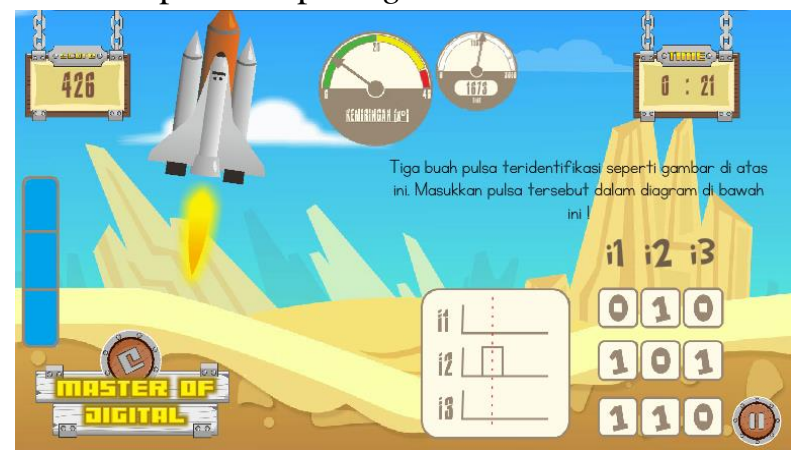

Gambar 5. Level 3

Level 3 di dalam game ini bercerita tentang pendaratan pesawat angkasa di bulan. Mahasiswa akan dihadapkan pada beberapa soal tentang penyederhanaan fungsi logika. Tiap detik berjalan pesawat akan mengalami kemiringan yang memungkinkannya untuk jatuh. Apabila Mahasiswa menjawab pertanyaan dengan benar maka kemiringan pesawat akan kembali seperti semula. 


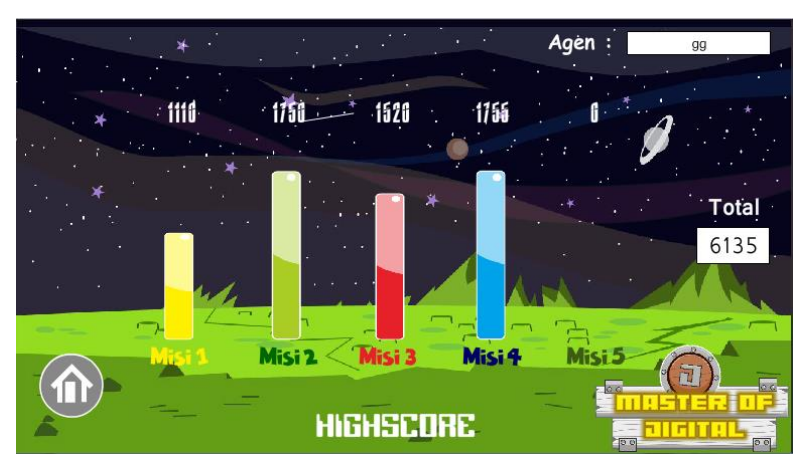

Gambar 6. Skor Tertinggi

Menu skor tertinggi berisi jumlah skor yang diraih oleh masing-masing pengguna pada setiap level. Setiap level memiliki materi yang berbeda-beda yang dapat ditunjukkan pada layar setiap kali level mendapat perlakuan dari pointer.

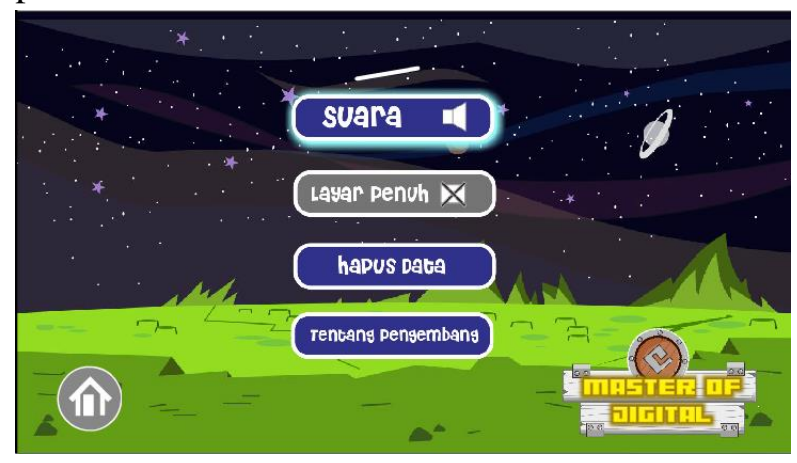

Gambar 7. Menu Pengaturan

Menu pengaturan berisi menu untuk mengatur suara, ukuran layar, reset data, dan menampilkan tentang pengembang. Proses reset data di dalam menu pengaturan dilakukan dengan mengubah variabel data yang sudah tersimpan di register menjadi data awal

\section{Kelayakan Game Edukasi}

\section{a. Kelayakan oleh Ahli Materi}

Penilaian kelayakan materi dilakukan oleh 2 ahli materi. Ahli materi tersebut berasal dari Dosen Jurusan Pendidikan Teknik Elektro Fakultas Teknik Universitas Negeri Yogyakarta. Aspek yang dinilai yaitu tujuan pembelajaran, kualitas isi, dan umpan balik dan motivasi. Skor penilaian oleh ahli materi dapat dilihat pada Tabel 1.
Tabel 1. Hasil Penilaian oleh Ahli Materi

\begin{tabular}{|c|c|c|c|}
\hline No & Aspek & $\begin{array}{l}\text { Rerata } \\
\text { Skor }\end{array}$ & Kategori \\
\hline 1 & $\begin{array}{c}\text { Tujuan } \\
\text { Pembelajaran }\end{array}$ & 14 & $\begin{array}{l}\text { Sangat } \\
\text { Layak }\end{array}$ \\
\hline 2 & Kualitas Isi & 47,5 & $\begin{array}{l}\text { Sangat } \\
\text { Layak }\end{array}$ \\
\hline 3 & $\begin{array}{c}\text { Umpan Balik dan } \\
\text { Motivasi }\end{array}$ & 11,5 & $\begin{array}{l}\text { Sangat } \\
\text { Layak }\end{array}$ \\
\hline \multicolumn{2}{|c|}{ Total Skor Rerata } & 73 & $\begin{array}{l}\text { Sangat } \\
\text { Layak }\end{array}$ \\
\hline
\end{tabular}

Berdasarkan Tabel 1 dapat diketahui bahwa penilaian materi pada aspek tujuan pembelajaran mendapatkan rerata 14 dengan kategori "sangat layak". Penilaian pada aspek kualitas isi mendapatkan rerata 47,5 dengan kategori "sangat layak". Penilaian pada aspek umpan balik dan motivasi mendapatkan rerata 11,5 dengan kategori “sangat layak". Total skor rerata oleh ahli materi sebesar 73 dengan kategori "sangat layak".

\section{b. Kelayakan oleh Ahli Media}

Penilaian kelayakan media dilakukan oleh 3 dosen sebagai ahli media. Ahli Media tersebut berasal dari Dosen Jurusan Pendidikan Teknik elektro Fakultas Teknik Universitas Negeri Yogyakarta. Aspek yang dinilai yaitu desain presentasi, penggunaan interaksi, aksesbilitas, dan penggunaan kembali. Skor penilaian oleh ahli media dapat dilihat pada Tabel 2.

Tabel 2. Hasil Penilaian oleh Ahli Media

\begin{tabular}{|c|c|c|c|}
\hline No & Aspek & $\begin{array}{c}\text { Rerata } \\
\text { Skor }\end{array}$ & Kategori \\
\hline 1 & $\begin{array}{l}\text { Desain } \\
\text { Presentasi }\end{array}$ & 33,67 & $\begin{array}{l}\text { Sangat } \\
\text { Layak }\end{array}$ \\
\hline 2 & $\begin{array}{l}\text { Penggunaan } \\
\text { Interaksi }\end{array}$ & 21,33 & Layak \\
\hline 3 & Aksesbilitas & 22,33 & Layak \\
\hline 4 & $\begin{array}{l}\text { Penggunaan } \\
\text { Kembali }\end{array}$ & 6,67 & $\begin{array}{c}\text { Sangat } \\
\text { layak }\end{array}$ \\
\hline \multicolumn{2}{|c|}{ Total Skor Rerata } & 84 & Layak \\
\hline
\end{tabular}

Berdasarkan Tabel 2 dapat diketahui bahwa penilaian materi pada aspek desain presentasi mendapatkan rerata 33,67 dengan kategori "sangat layak". Penilaian pada penggunaan interaksi mendapatkan rerata 21,33 dengan kategori "layak". Penilaian pada aspek aksesbilitas mendapatkan rerata 22,33 dengan kategori "layak". Penilaian pada aspek 
penggunaan kembali mendapatkan rerata 6,67 dengan kategori "sangat layak". Total skor rerata oleh ahli media sebesar 84 dengan kategori "layak".

\section{c. Kelayakan oleh Responden}

Penilaian kelayakan oleh Mahasiswa dilakukan oleh 33 responden yang berasal dari Mahasiswa Jurusan Pendidikan Teknik Elektro Universitas Negeri Yogyakarta. Aspek yang dinilai yaitu tujuan pembelajaran, kualitas isi, umpan balik dan motivasi, desain presentasi, penggunaan interaksi, aksesbilitas. Skor penilaian oleh mahasiswa dapat dilihat pada Tabel 3.

Tabel 3. Hasil Penilaian oleh Mahasiswa

\begin{tabular}{|c|c|c|c|}
\hline No & Aspek & $\begin{array}{c}\text { Rerata } \\
\text { Skor }\end{array}$ & Kategori \\
\hline 1 & $\begin{array}{l}\text { Tujuan } \\
\text { Pembelajaran }\end{array}$ & 6,21 & Layak \\
\hline 2 & Kualitas Isi & 9,03 & Layak \\
\hline 3 & $\begin{array}{l}\text { Umpan Balik } \\
\text { dan Motivasi }\end{array}$ & 6,30 & Layak \\
\hline 4 & $\begin{array}{l}\text { Desain } \\
\text { Presentasi }\end{array}$ & 9,00 & Layak \\
\hline 5 & $\begin{array}{l}\text { Penggunaan } \\
\text { Interaksi }\end{array}$ & 15,39 & Layak \\
\hline 6 & Aksesbilitas & 15,70 & Layak \\
\hline \multicolumn{2}{|c|}{ Total Skor Rerata } & 54,61 & Layak \\
\hline
\end{tabular}

Berdasarkan Tabel 3 dapat diketahui bahwa penilaian Mahasiswa pada aspek tujuan pembelajaran mendapatkan rerata 6,21 dengan kategori "layak". Penilaian pada aspek kualitas isi mendapatkan rerata 9,03 dengan kategori "layak". Penilaian pada aspek umpan balik dan motivasi mendapatkan rerata 6,30 dengan kategori "layak". Penilaian pada aspek desain presentasi mendapatkan rerata 9,00 dengan kategori "layak". Penilaian pada penggunaan interaksi mendapatkan rerata 15,39 dengan kategori "layak". Penilaian pada aspek aksesbilitas mendapatkan rerata 15,70 dengan kategori "layak". Total skor rerata oleh Mahasiswa sebesar 54,61 dengan kategori "layak".

\section{SIMPULAN}

Pengembangan Game Edukasi Sebagai Media Pembelajaran Mata Kuliah Praktik Teknik Digital dengan menggunakan ADDIE sebagai model pengembangannya memiliki penjabaran sebagai berikut : (1) Tahap analisis meliputi analisis kurikulum, analisis materi, dan analisis karakter mahasiswa yang dilakukan melalui observasi dan wawancara kepada sumber. (2) Tahap desain meliputi perancangan data, perancangan navigasi, dan perancangan user interface. (3) Tahap pengembangan dan implementasi meliputi pengembangan algoritma, pengembangan user interface, dan pengembangan program. (4) Tahap evaluasi meliputi penilaian oleh pengguna akhir, kritik atau saran, dan pengembangan media lebih lanjut berdasarkan data hasil evaluasi.

Tingkat kelayakan game edukasi sebagai media pembelajaran mata kuliah praktik teknik digital oleh ahli materi mendapatkan rerata skor 73 dengan kategori "sangat layak" untuk digunakan sebagai media pembelajaran dari rerata skor tertinggi sebesar 84. Rerata skor total tersebut berasal dari rerata skor aspek tujuan pembelajaran sebanyak 14 , rerata skor aspek kualitas isi sebanyak 47,5, dan rerata skor aspek umpan balik dan motivasi sebanyak 11,5. Penilaian kelayakan oleh ahli media mendapatkan rerata skor total sebanyak 84 dengan kategori "layak" untuk digunakan sebagai media pembelajaran dari rerata skor total tertinggi sebanyak 104. Rerata skor total tersebut berasal dari rerata skor aspek desain presentasi sebanyak 33,67, rerata skor aspek penggunaan interaksi sebanyak 21,33, rerata skor aspek aksesbilitas sebanyak 22,33, dan rerata skor aspek penggunaan kembali sebanyak 6,67. Respon dari pengguna akhir dengan responden sebanyak 33 mahasiswa, menyatakan bahwa $27 \%$ mahasiswa menyatakan bahwa game edukasi "sangat layak" untuk digunakan sebagai media pembelajaran. $73 \%$ mahasiswa menyatakan bahwa game edukasi "layak" untuk digunakan sebagai media pembelajaran. Berdasarkan data tersebut dapat diambil 
kesimpulan bahwa game edukasi yang telah dibangun "layak" untuk digunakan sebagai media pembelajaran.

\section{DAFTAR RUJUKAN}

Anonim. 2016. ADDIE Model. Diakses dari http://www.csuchico.edu/idts/addie.php.p ada 16 Juni 2016

Ariesto Hadi Sutopo. 2012. Teknologi Informasi dan Komunikasi dalam Pendidikan. Yogyakarta: Graha Ilmu.
Leacock, T. L., \& Nesbit, J. C. 2007. A Framework for Evaluating the Quality of Multimedia Learning Resources. Jurnal Simon Fraser University 2007

Nana Sudjana \& Ahmad Rivai. 2013. Media Pengajaran. Bandung: Sinar Baru

Rusman, Deni Kurniawan \& Cepi Riyana. 2013. Pembelajaran Berbasis Teknologi Informasi dan Komunikasi. Depok: PT Rajagrafindo Persada. 